\title{
Sickle cell disease in Western Nepal
}

\section{Rajan Pande ${ }^{1}$, Pragya Gautam Ghimire ${ }^{2}$, Priyankar Bahadur Chand ${ }^{3}$, Sharmila Gupta ${ }^{4}$}

${ }^{1}$ Chief consultant physician and Head of Department of Internal Medicine, Bheri Provincial Hospital, Bheri Zone, Province no-5, Nepal.

${ }^{2}$ Assistant Professor, Department of Pathology, Nepalgunj Medical College and Teaching Hospital, Bheri Zone, Province no-5, Nepal.

${ }^{3}$ Cofounder Sickle Cell Nepal, Kailali, Seti Zone, Province no-7, Nepal.

${ }^{4}$ Lecturer, Department of Pathology, Nepalgunj Medical College and Teaching Hospital, Bheri Zone, Province no-5, Nepal.

Received: December 18, 2018

Accepted: January 15, 2018

Published: January 30, 2019

Cite this paper:

Pande R, Ghimire P, Chand PB, Gupta S et al. Sickle cell disease in Western Nepal. Nepal Journal of Medical Sciences 2019;4(1):15-19.

\section{ABSTRACT}

Introduction: Since 2003, only few cases of sickle cell disease have officially been reported in Nepalese medical journals, and all reported patients belong to the Tharu ethnic group of Nepal. This is the first study that details sickle cell disease and carrier in 1250 individuals in western Nepal.

Methods: This is a retrospective review of the patients and carriers of sickle cell disease diagnosed by either a positive haemoglobin electrophoresis report or a positive high performance liquid chromatography (HPLC) report. Analysis was done using SPSS 20.

Results: Out of the 1250 individuals, 51.4\% were females. 601 (48.08\%) were patients with a form of sickle cell disease, the mean age was $24.5 \pm 12$ yrs years. Most patients came from Bardiya district. Most common symptoms were related to joint pain. The patients and carriers of sickle cell disease were mostly from Tharu ethnic group $(97.7 \%)$.

Conclusion: These data suggest that sickle cell disease and other haemoglobinopathies are more prevalent than previously reported among members of the Tharu ethnic group and other residents of western Nepal. More research is imperative to assess the burden of the sickle cell disease and other haemoglobinopathies in Nepal.

Key words: foetal haemoglobin; haemoglobinopathy; Nepal; sickle cell disease

Correspondence: Dr. Rajan Pande,

Chief consultant physician and Head of

Department of Internal Medicine,

Bheri Provincial Hospital, Bheri Zone,

Province no-5, Nepal.

Email address: nams.rajan66@gmail.com

Licensed under CC BY 4.0 International License which permits use, distribution and reproduction in any medium, provided the original work is properly cited 


\section{INTRODUCTION}

Sickle cell disease (SCD) is the most prevalent heritable genetic haemoglobinopathy, resulting from a single nucleotide polymorphism in the beta globin gene. Carriers of SCD are generally asymptomatic and partially resistant to severe Falciparum malaria. SCD can also be inherited alongside other genetic haemoglobinopathies such as beta thalassemia, thus patient can be double heterozygous for both sickle cell and beta thalassemia.[1-3]

The Tharus, an indigenous group who live in the Terai region of Nepal are known to have blood disorders that are associated with malaria resistance.[4-5] Although studies have previously reported blood disorders such as glucose-6-phosphate dehydrogenase deficiency, alpha thalassemia, and SCD in the Tharu community, only few cases of SCD have officially been reported in Nepali medical journals since 2003.[5-8] Here, we present the first largest study that provides data on demographic status and types of SCD reported in Western region of Nepal.

\section{METHODS}

This is a retrospective study of patients and their affected family members with sickle cell disease at Bheri Provincial Hospital, Nepalgunj. A total of 1459 individuals of haemoglobinopathies were seen between 2012 and 2018, out of which 1250 had sickle cell disease and carrier. Data of all patients and carriers with a haemoglobin electrophoresis report were collected. Data regarding socio-demographic information, diagnosis related information and symptoms of patients were recorded. Either a positive haemoglobin electrophoresis report or a positive high performance liquid chromatography (HPLC) report were included in this study. These reports more reliably confirm the haemoglobin variance and the type of haemoglobinopathy present in a patient.[9] Patients with thalassemia were excluded.

Analysis was done using SPSS version 20.

\section{RESULTS}

Out of 1250 patients and carriers, 608 (48.6\%) were male and $642(51.4 \%)$ were female. The mean age of patients and carriers was $24.5 \pm 12$ yrs. Maximum number of patients $381(30.5 \%)$ were in the age group $21-30$ years. Only $156(12.5 \%)$ patients and carriers were under the age of 11 years. Around 1221 (97.7\%) of the patients and carriers belonged to the Tharu ethnic group of Nepal. Rest were non-Tharus- Yogi, B C, Raidas etc. All patients were from the Western, Mid-Western or Far-Western region of Nepal. Most patients and carriers were from Bardiya district of Nepal 518 (41.4\%) followed by Dang 356 (28.5\%), Banke 144 (11.5\%), Kailali 191 (15.3\%), Surkhet 32 (2.6\%), Kanchanpur four (0.3\%), Kapilvastu three $(0.2 \%)$, Nawalparasi one $(0.1 \%)$ and Pyuthan one $(0.1 \%)$.

Haemoglobin electrophoresis and HPLC tests were used to distinguish the types of haemoglobinopathies. The various types of sickle cell disease are as shown in Table 1.

Most of them had visited multiple health facilities and traditional faith healers before the final diagnosis. Joint pain was the most common symptom noted followed by recurrent jaundice. There were reports of other symptoms: like acute vaso-occlusive crisis, acute chest syndrome, avascular necrosis of bilateral femoral head, exact frequencies of these conditions were not documented. None of them had leg ulcers, stroke and priapism. 
Table 1. Type of Sickle cell disease and carrier.

Types of Sickle Cell Disease

Sickle Cell Trait

Sickle Cell Anemia

Sickle haemoglobin (HBS) / Hereditary persistence of foetal

haemoglobin ( $\mathrm{HPFH})$

HBS/ Beta thalassemia

Sickle Alpha thalassemia

Hemoglobin SE (Hb SE)

Sickle haemoglobin C ( HBC)

Total
Frequency

Percentage

641

51.3

275

22.0

117

9.7

205

16.4

8

0.6

3

0.2

1

0.1

1250

$100 \%$

\section{DISCUSSION}

All 1250 patients and carriers were from malaria endemic regions of Nepal. Most of them were from the Tharu ethnic group. The scenario in Nepal is similar to that of India's where SCD is commonly seen in tribal populations of malaria endemic regions of Central and South India.[10] Notably, the mean age of patients and carriers in this study was 24.5 years. This suggests that most patients with SCD and other haemoglobinopathies in Nepal are getting diagnosed later in their lives. Only $12.5 \%$ of patients and carriers were under the age of 11 years in this study. All patients and carriers reported here were from western Nepal where the study was conducted. Most patients and carriers came from Bardiya, which is the second most populous district for Tharus in Nepal.[11] This is similar to other study.[6] $\mathrm{Hb} \mathrm{S}$ has been documented in various tribal communities of Gujarat, India.[12] The disease is found predominantly among scheduled caste, scheduled tribe and other backward classes.[13] 
Most of the individuals in our study were female which is in contrast to other studies.[6,14]

Higher $\mathrm{HbF}$ levels in SCD is associated with a reduced rate of acute pain, fewer leg ulcers, less osteonecrosis, less frequent acute chest syndromes, and reduced disease severity.[15] The cases in Nepal may be similar to a mild form of SCD found in India and Saudi Arabia, which is associated with the Arab-Indian $\beta$ globin gene cluster haplotype.[16] Moreover, the symptoms of pain and vaso-occlusive crisis are common to SCD patients globally.[1]

This study shows that SCD are common in the Tharus. It is highly recommended that neonatal screening be put in place so that children with SCD are identified and receive medical interventions; cost-effective interventions such as immunizations and penicillin prophylaxis can reduce the risk of infection early in life and help prolong life of SCD patients. $[17,18]$

There are several limitations in our study. Firstly, it is a retrospective study based on previous records. As different methods (Agarose gel, cellulose acetate, HPLC Biorad D10, HPLC variant analysis method, capillary electrophoresis) were used, the individual variations were however not considered in this study. Besides, a difference in prevalence of SCD in different subcaste of the same Tharu community was not undertaken. The symptoms reported in the study were only recorded by a single doctor and some symptoms were self-reported by patients. Furthermore, this study lacked data on complete blood count and mean corpuscular volume, which are valuable to confirm diagnosis of haemoglobinopathies. Despite these limitations, this study does aggregate information for the largest cohort of haemoglobinopathy patients and carriers in
Nepal and the results reported are consistent with the SCD trends in South Asia.

\section{CONCLUSION}

This study shows the high prevalence of sickle cell disease in the Tharu community of Western Nepal. Hence early screening programs need to be implemented in order to detect and timely manage the cases. Additional research is imperative to assess the burden of the SCD in Nepal.

\section{CONFLICT OF INTEREST}

None

\section{SOURCES OF FUNDING}

None

\section{DISCLOSURE}

- Population based screening by NHRC, which is now running in Barbardiya municipality, Bardiya (which includes former Baniyavar VDC, Dadhawar VDC, Mangragadi VDC and Padnaha VDC) was based on these preliminary clinical data.

- Bipana Nagarik Aausadhi Upachar Kosh Nirdeshika(Amended) 2071, where sickle cell anaemia was added by meeting of cabinet of ministers in 2071-04-22 AD was based on these preliminary data.

\section{REFERENCES}

1. Rees DC, Williams TN, Gladwin MT. Sickle-cell disease. Lancet. 2010;376(9757):2018-31. doi: 10.1016/S0140-6736(10)61029-X.

PubMed PMID: 21131035.

2. Piel FB, Patil AP, Howes RE, Nyangiri OA, Gething PW, Dewi M, et al. Global epidemiology of sickle haemoglobin in neonates: a contemporary 
geostatistical model-based map and population estimates. Lancet. 2013;381(9861):142-51. doi: 10.1016/S0140-6736(12)61229-X. PubMed PMID: 23103089; PubMed Central PMCID: PMCPMC3547249.

3. Grosse SD, Odame I, Atrash HK, Amendah DD, Piel FB, Williams TN. Sickle cell disease in Africa: a neglected cause of early childhood mortality. Am J Prev Med. 2011;41(6 Suppl 4):S398-405. doi: $\quad$ 10.1016/j.amepre.2011.09.013. PubMed PMID: 22099364; PubMed Central PMCID: PMCPMC3708126

4. Terrenato L, Shrestha S, Dixit KA, Luzzatto L, Modiano G, Morpurgo G, et al. Decreased malaria morbidity in the Tharu people compared to sympatric populations in Nepal. Ann Trop Med Parasitol. 1988;82(1):1-11. PubMed PMID: 3041928.

5. Modiano G, Morpurgo G, Terrenato L, Novelletto A, Di Rienzo A, Colombo B, et al. Protection against malaria morbidity: near-fixation of the alpha-thalassemia gene in a Nepalese population. Am J Hum Genet. 1991;48(2):390-7. PubMed PMID: 1990845; PubMed Central PMCID: PMCPMC1683029.

6. Shrestha A, Karki S. Analysis of sickle hemoglobin. Journal of Pathology of Nepal. 2013;3(6):437-40.

7. Adhikari R, Shrestha T, Shrestha R. Sickle cell disease-case reports. J Nepal Med Assoc. 2003;42:36-8.

8. Amatya A, Choudhary R, Zeher S, Gurung G, Rana A. Sickle cell anemia complicated by Hepatitis $\mathrm{E}$ infection in pregnancy. Journal of Institute of Medicine. 2008;29(3).

9. Bridges KR, Pearson HA. Anemias and other red cell disoders: McGraw Hill Medical; 2008.
10. Kar BC, Satapathy RK, Kulozik AE, Kulozik M, Sirr S, Serjeant BE, et al. Sickle cell disease in Orissa State, India. Lancet. 1986;2(8517):1198-201. PubMed PMID: 2430154.

11. CBS, Nepal. National Population Census 2011. (Central Bureau of Statistics, Nepal, 2013). at http://cbs.gov.np/wpcontent/uploads/2013/10/CasteEthinicity\%20and\%20Language.pdf

12. El-Hazmi MA, Al-Hazmi AM, Warsy AS. Sickle cell disease in Middle East Arab countries. Indian J Med Res. 2011;134(5):597.

13. Shrikhande A, Dani A, Tijare J, Agrawal A. Hematological profile of sickle cell disease in central India. Indian Journal of Hematology and Blood Transfusion. 2007;23(3-4):92-8.

14. K Kamble á, Chaturvedi P. Epidemiology of sickle cell disease in a rural hospital of central India. Indian Pediatr. 2000;37(4):391-6.

15. Kamble M, Chaturvedi P. Epidemiology of sickle cell disease in a rural hospital of central India, Indian Pediatr. 2000;37:391-6.

16. Akinsheye I, Alsultan A, Solovieff N, Ngo D, Baldwin CT, Sebastiani P, et al. Fetal hemoglobin in sickle cell anemia. Blood. 2011;118(1):19-27.

17. Ngo D, Bae H, Steinberg MH, Sebastiani P, Solovieff N, Baldwin CT, et al. Fetal hemoglobin in sickle cell anemia: genetic studies of the Arab-Indian haplotype. Blood Cells Mol Dis. 2013;51(1):22-6.

18. Steinberg MH. Management of sickle cell disease. $\mathrm{N}$ Engl $\mathrm{J}$ Med. 1999;340(13):1021-30 